\title{
"This Is a Matter of Numbers, Not of Heart". Re-signing Shock Labor in 1970s Film
}

\author{
Andrea Matošević \\ Juraj Dobrila University of Pula \\ Centre for Cultural and Historical Research of Socialism (CKPIS) \\ Department of Studies in Italian Language, Pula, Croatia
}

The 1970s mark a turning point in the representation of "exemplary workers", shock workers and work heroes, who had for years been part of the enterprise to increase (mainly) industrial production in state socialist countries and beyond. From its very beginnings, shock labor was inseparable from its representation in the mass media, mainly documentaries and propaganda films. In contrast, in the early 1970s, post-war work successes turn into a caput mortuum, a worthless residue of early "official" socialism. Accordingly, the image of the shock labor movement and of shock workers-as-innovators turns out to be interesting material for artists and filmmakers, who resurrect and rediscover this long-forgotten idea, turning it into an instrument of criticism of the system that advocated it, without criticizing the movement's most prominent actors. Yugoslav, Polish and Italian directors Bahrudin Bata Čengić, Andrzej Wajda and Elio Petri in their films Slike iz života udarnika (Images from the Life of a Shock Worker, 1972), Człowiek z marmuru (Man of Marble, 1976) and La classe operaia va in paradiso (Lulù the Tool, 1972) respectively, resign the essence of work heroism. The problem of increasing production quotas, a "good and happy family life" accompanied by indispensable cultural education and the inclusion of workers in political life are some of the prevailing topics these directors use to build their own eclectic, critical as well as apologetic vision of the shock labor past or present.

Key words:

shock labor, Stakhanovism, film, Alija Sirotanović, socialism, Slike iz života udarnika

Andrzej Wajda's Człowiekz marmuru (Man of Marble) from 1976 is probably the most famous feature film dealing with work heroism, Stakhanovism, or 
shock labor. ${ }^{1}$ This is a movement that begun in the Soviet Union in 1935 as an attempt to increase industrial production, which gained some popularity during the Second World War (even in countries such as e.g. Great Britain; cf. Berneri 1942) and was characteristic of the period immediately following the Second World War in state socialist countries. Still, Człowiek z marmuru is among the last films in a long line of celluloid interpretations of work heroism and hero workers. However, the intertextuality that surrounds it makes it relevant for Yugoslav shock-labor imagology: it seems that even today many assume that Wajda's famous film was inspired by Alija Sirotanović, a Yugoslav Hero of Socialist Labor. Thus, the Serbian weekly Vreme published an article that admonished: "Andrzej Wajda's Człowiek $Z$ marmuru was not inspired by Alija Sirotanović, but by Mateusz Birkut, the Polish Stakhanovite and the recipient of the Socialist Worker Hero medal. He was not a miner, but a brick layer, who had earned his medal in 1952 when he (together with five assistants) laid 30,000 bricks in a single shift, setting a world record he subsequently repeatedly broke“ (Majdin 2011).

Although Wajda's Mateusz Birkut is a fictional, allegorical character, ${ }^{2}$ and Alija Sirotanović is a historical figure whose work became mythical, their professional shock-labor genesis is identical. It can be traced back to Aleksei Stakhanov, a miner who, during the night shift of 31 August, 1935 in the Soviet (Ukrainian) Donbas colliery, mined 102 tons of coal, exceeding the average quota by fourteen times and earning 200 instead of the average 23-30 rubles (Matošević 2011: 219-220; Siegelbaum 1988). From its very beginnings Stakhanovism, being a movement based on work enthusiasm, was mediated to the public by means of, among other things, documentary and propaganda films, ${ }^{3}$ such as Happy Housewarming,

${ }^{1}$ Shock labor is a broader and older notion than Stakhanovism. These two terms are not synonymous, but we will be treating them as such throughout the text for the purpose of simplicity. Udarnichevstvo is a movement that originated during the Civil War in Russia, when individuals had to perform especially difficult and hazardous tasks in battle, while it assumed a completely new meaning in 1927/1928, when isolated groups of workers, mostly Komsomol (Kommunistichesky Sojuz Molodezhi - Young Communist League) members, organized brigades which completed tasks far beyond the assigned scope. Stakhanovism, on the other hand, is a movement whose history and significance are connected almost exclusively with the industrial milieu and the heroic, exponential production increase in all branches of economy.

${ }^{2}$ Człowiek $z$ marmuru is based on an incident Wajda's friend and colleague Jerzy Bossak read about in a newspaper: a brick-layer had come to the employment office in Nowa Huta, but he was not given a job because only foundry workers were needed. However, one of the clerks remembered his face: once he was a well-known labor leader (http://www.wajda.pl/en/filmy/film20.html).

3 At http://www.soviethistory.org/index.php?page=subject\&show=video\&SubjectID=193 6stakhanov\&Year=1936\&navi=byYear. All available films on the site are excerpts from larger 


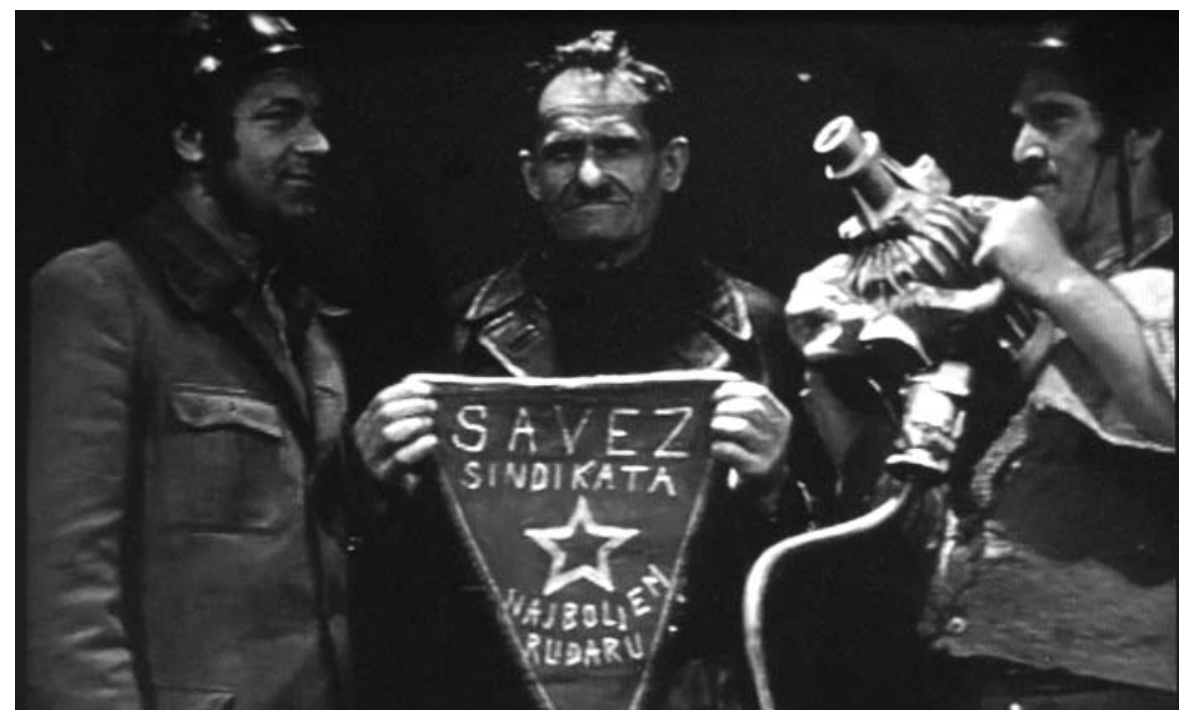

Figure 1. Adem Čejvan, Alija Sirotanović and Stojan Aranđelović, still from the movie Slike iz života udarnika

Comrade Busygin! (1936), Aleksei Stakhanov ("At home with Stakhanov", 1936), The Stakhanov Movement ("Stakhanov at his Record-Breaking Feat", 1938). ${ }^{4}$ After the Second World War the movement was appropriated by the newly-emerged state socialist countries, later disintegrating and being swept back to the past. Consequently, not only were its work heroes forgotten, but they became a thorn in the side of the establishment. The script for Człowiek $z$ marmuru had been banned for years and the film was made only after Władysław Gomułka stepped down from his position as First Secretary. ${ }^{5}$ Its complementary sequel Człowiek z żelaza (Man of Iron) ${ }^{6}$

documentaries, and apart from Happy Housewarming, Comrade Busygin, which was part of Soiuzkinozhurnal no. 1, we were unable to track their original Russian titles or directors.

4 "Documentary" films about work successes of Yugoslav workers were made during Yugoslav socialism. They followed a similar socialist realist principle. Among the most famous ones are those about Sirotanović's breaking of Stakhnanov's record documented in Zoran Markuš's Sto dana $u$ Brezi (One Hundred Days in Breza, 1949), Filmski pregled 5 (Film Review No. 5, 1950) by Branko Bauer and Rudolf Sremec's Događaj u Raši (An Event in Raša, 1950) about Antun Bičić, a shock worker from Raša.

${ }^{5}$ Andrzej Wajda. Official Website of Pollish Movie Director. At http://www.wajda.pl/ (accessed 14 December 2012).

${ }^{6}$ Człowiek z marmuru (Man of Marble), Poland, Andrzej Wajda, 1976. Agnieszka (Krystyna Janda) is a twenty-eight-year-old TV director, determined, but thwarted, to film a documentary about Mateusz Birkut (Jerzy Radziwiłowicz), a brick layer, a work hero from the 1950s, the bearer of the honorary title of the Builder of Nowa Huta (part of Kraków). During her research she meets Birkut's ex wife, now alcoholic, and Jerzy Burski, the director who encouraged Birkut to set the working 
Andrea Matošević, “This Is a Matter of Numbers, Not of Heart”. Re-Signing Shock Labor in 1970s Film. Nar. umjet. 50/1, pp. 12-39

\section{from 1981, like Wajda himself, had a similar fate:}

The Polish government unsuccessfully attempted to withdraw Man of Iron as Poland's entry in the Academy Awards. Wajda himself was originally placed in a concentration camp, then under house arrest, and is now in Paris directing a film about Danton. Krystyna Janda, who plays the principal character in Man of Marble, also lives in Paris, which has rapidly become the international center for Polish exile activity. (DiCaprio 1982: 7)

Correspondingly, the film Slike iz života udarnika (Images from the Life of a Shock Worker) ${ }^{7}$ directed by Bata Čengić, was withdrawn from the competition at the Festival of Yugoslav Feature Film in Pula in 1972. In a statement at the press conference, the head of the jury, Stipe Šuvar, ${ }^{8}$ said:

One of the issues is why the jury accepted Arif Tanovićs suggestion that Bata Čengić's film is politically unacceptable. I think that we, the jury, as a collective body, have not disqualified the film Slike iz života udarnika due to political reasons, or, if in individual presentations there was some reference to

record and filmed his accomplishments - the laying of 30, 509 bricks in a single shift - giving rise to Birkut's worker cult, as well as his own directing career through successful documentaries Poczatek miasta (A city is Born) and Oni budują nasze szczęście (Building our Happiness). Sabotage during Birkut's demonstration of his work method, when his palm gets burned with a hot brick handed to him by his first aide Witek, marks the start of Birkut's decline as a work icon. Determined to discover the truth, he fails to extricate himself from a web of intrigues, ending up in prison, having lost his family and glory. In Człowiek z żelaza, Poland, Andrzej Wajda, 1981, the sequel to Człowiek $z$ marmuru, Mateusz Birkut's son Maciek Tomczyk is one of the leaders of the Solidarność movement in the shipyards of Gdańsk. Mateusz Birkut is killed during the strike.

${ }^{7}$ Slike iz života udarnika, SFRY, Bata Čengić, 1972. The movie was inspired by the life and work successes of the first Yugoslav shock worker Alija Sirotanović, who, along with his fellow shock workers Risto Mijatović, Edhem Škorić, Abdurahman Babajić, Džemal Ramović and Alojz Petek, participated in the making of the film as an advisor. According to Daniel J. Goulding, Čengić "[f]ollows the rise and fall of a Bosnian miner Adem, foreman of a shock work brigade. Through hard work and enthusiasm they compensate for the lack of machines and difficult conditions of work in the mines. As a reward for beating Stakhanov's record they became famous, e.g. their efforts are filmed and celebrated in the whole country" (Goulding 2004: 110). Moreover, Adem enjoys the support of the Communist Party - his village gets electricity, he visits the lake of Bled with his comrades, he gets new furniture, a bust that can be cast in silver or gold - a clear tribute to his achievements, he visits Moscow and meets Stakhanov himself, they drink vodka together and Stakhanov names them his successors, since his own strength is waning. Čengić builds the film on a "binary narrative" - on the one hand there is the idealized picture, scenes of tableaux vivants of strike laborers in poses hardly depicting the complexity of issues and the difficulty of their situation, and on the other he highlights the downside of work successes of shock workers - grueling work, relations with politics, illness and, finally, anonymity.

${ }^{8}$ Stipe Šuvar was a sociologist and one of the leading Croatian and Yugoslav politicians. In 1974 he became the Croatian Minister of Education. 
political matters and motives, my personal opinion, which can be confirmed if you listen to the whole discussion on the film carefully, is that the principal reason was that its topic was not adequately artistically expressed. (Šuvar, press conference, author's personal archive) ${ }^{9}$

Together with the Italian motion picture director and screenwriter Elio Petri's award-winning La classe operaia va in paradiso (Lulù the Tool) ${ }^{10}$ these films make up a significant international production film triad which questions Stakhanovism. They take a critical stance towards the movement that was used by post-war governments in an attempt to revive their respective economies, and to leave an impression of placing the worker in the center of the political, economic and cultural spheres. Each of the directors, in line with the local context in which they question shock labor/ Stakhanovism, robs the movement of its enthusiasm and emasculates exemplary workers, but does not invite the audience to demystify them. A caput mortuum, a worthless residue of early state socialism, the image of the shock labor movement and its most active participants became a favorite topic for artists and film-makers. Resurrecting shock labor, especially during the 1970s, they rediscover this long-forgotten idea and transform it into an instrument of criticism of a system that advocated them, without criticizing the movement's active participants. Additionally, Elio Petri does not use the theme of exceeding work quotas/Stakhanovism by organizing and intensifying piecework to reflect on the Italian industrial past, but

${ }^{9}$ Here is the original transcription of Stipe Šuvar's monologue: "Jedno je od pitanja zbog čega je žiri prihvatio sugestiju Arifa Tanovića da je film Bate Čengića politički neprihvatljiv. Mislim da film Slike iz života udarnika, nismo taj film kao žiri, kao kolektivno tijelo, odbacili zbog političkih razloga ili, ako je bilo u pojedinačnim izlaganjima i spominjanja političkih momenata i političkih motiva, čini mi se, moj je osobni utisak, a može se to steći i pažljivim praćenjem i slušanjem cijele rasprave koju smo o tom filmu vodili da je tu naš osnovni motiv bio što smo stekli da adekvatno, umjetnički nije temu izrazio."

${ }^{10}$ La classe operaia va in paradiso, Elio Petri, 1972. Lulù Massa (Gian Maria Volonté) is a turner in a Milan factory, the champion of piecework which supports his two families. At the age of thirtyone he had already survived two chemical poisonings and has an ulcer. His fellow workers hate him because of his incessant increases of work quotas, while the boss, the employer, considers him his best worker. An accident in which he loses his finger turns him from a best Stakhanovite into a fierce protester and opponent of piecework, which leads to his layoff. He joins the student left, which sees his case only as an instance of individual injustice, not a "class" issue. He reaches out to the union which gets him his job back. His only comfort and "sincere social contact" come from conversations with an old worker Militina - a former fellow worker, now committed to a mental hospital, with whom Lulù involuntarily identifies. The final allegorical scenes in the film show workers working on an assembly line, discussing Lulù's dream through a chain of Chinese whispers - tearing down the wall of heaven, a haze obscuring everything except Militina and Lulù emerging from a cloud of thick smoke. 
rather to indicate its contemporary problems in the late 1960s and early 1970s - "the relationship between man and machine, the union and the new left, student protests and workers' struggles, owner repression and technological progress" (Morandini, Morandini and Morandini 2002).

However, although the three films, which were produced within five years, display diverse authorial approaches to the theme, they nevertheless, mutatis mutandis, present it to the audience using very similar dominant topoi. The deconstruction of specific markers that were to signify happiness, well-being and faith in the future of the "new socialist man" is a dramaturgical technique used particularly by Andrzej Wajda and Bata Čengić. The problem of increasing work quotas, a "good and happy family life", the all-important cultural improvement and the inclusion of workers in political life - these are some of the prevailing topics that all the directors use to build their own eclectic, critical, and apologetic vision of the shock-labor past (Bata Čengić and Andrzej Wajda) or present (Elio Petri). We argue that this forms are the very core of the process of re-signation (Vattimo 2008: 134) of the Stakhanovite movement. The Italian film is a particularly interesting example, given that Italy was not part of the Eastern Bloc or indeed a socialist country. The problem of the implementation and repercussions of Stakhanovism that Petri addresses in the context of an Italian factory shows that the movement was not tied exclusively to statesocialist countries or the post-war period. Also, it indicates that although the range of manifestations subsumed under the label "Stakhanovism" is very wide, its different strands are brought together by the demand for increased work quotas. ${ }^{11}$ However, before we analyze the three films, let us examine the official image of exemplar workers in the mid and late 1930s, the period when the Stakhanovite competitions were introduced into factories and plants.

${ }^{11}$ Although the issues of production dealt with in Petri's film could be analyzed from a Fordist production point of view, we believe that a Taylorist textual approach is more fitting. Not only because it is inscribed in the Fordist philosophical and practical base, i.e. it precedes it, but also because Taylorism generated the Italian version of Fordism called Bedaux system during the 1930s which would therefore be a more appropriate reference point. However, to avoid excessive explanations of the differences and similarities between these notions, we refer to them simply as Taylorism, which is inscribed and theoretically covers all the other ones. 


\section{EROSION OF EXEMPLARINESS}

Nearly all of the mentioned socialist-realist documentary-propaganda films about exemplary workers made during the mid-1930s in the Soviet Union put strong emphasis on portraying the exemplary worker's "good private life". For instance, Happy Housewarming, Comrade Busygin contains a scene in which Alexandr Kharitonovich Busygin and his family move into their new apartment, which is an exclusive benefit for the best Stakhanovite and a renowned master from the community of Molotov automobile factory. The scenes depicting Busygin's children and wife, her folding clean linen into a drawer, putting flowers on the table and asking her husband "Is this alright?" all the while listening to music from a record player, and him browsing a book in his very own library, are all visualizations of Stalin's rhetorical question addressed to the first Federal Council of Stakhanovites in 1935: "How did the Stakhanovite movement become so popular? What reasons lie behind its spread across our entire economy, across all regions and districts of our great country?", as well as his answer - "I can give you several reasons - life has become better, comrades; life has become happier. When life is happy, people work well. Hence the high work quotas. Hence the heroes and heroines of work. This is the source of the Stakhanovite movement" (Staljin 1946: 13). The film Aleksei Stakhanov. At Home with Stakhanov follows a similar pattern - introductory bucolic scenes of Stakhanov's house surrounded by a multitude of flowers and by nature are followed by scenes of Stakhanov enthusiastically immersed in intellectual labor, sitting at his desk over a mathematics textbook, overseen by a framed portrait of his smiling wife, working diligently, head bent, on a new technical project. The scene of a neatly laid out table dominated by a samovar is followed by a scene in which his wife, feeding the chickens and waving to her husband who is leaving the yard in a new car - "a beautiful present of comrade Ordzhonikidze".12

When analyzing these films one should bear in mind their documentary and propaganda character, the socialist-realist "aesthetical-pedagogical" perspective involved in their creation, which, according to Boris Groys, "candidly formulates the principle and strategy of its mimesis: although it advocates a strictly 'objective', 'adequate' rendering of external reality, at the

${ }^{12}$ Grigory Ordzhonikidze, also known as Sergo, was a close friend of Stalin's and Commissar of the Soviet Heavy Industry from 1932 until his death in 1937. 
same time it stages or produces this reality. More precisely, it takes reality that has already been produced by Stalin and the party, thereby shifting the creative act onto reality itself, just as the avant-garde had demanded" (Groys 2011: 55). ${ }^{13}$ The tension between the necessity of building a "good private, family life" on the one hand, and the insistence on triumphant professional success on the other has been relieved, according to the movement's advocates, by a fundamental work ethos, because a "shock worker should be considered as someone who works at the factory exactly seven hours, since Soviet power does not permit anyone to work more, who regularly goes to the cinema, visits others, engages in sport and at the same time fulfills all production tasks" (Siegelbaum 1988: 225). ${ }^{14}$ Such an image of the Stakhanovite worker as "a good family man" should have seemed as an almost natural consequence of his working ethos. Namely, as suggested by Gail Lapidus, the family "serve[d] above all as a model of social order, and for this purpose marital stability was essential" (cf. Siegelbaum 1988: 237). It is this very aspect of the role-model worker's life that was abandoned by Wajda, Čengić and Petri in their 1970s feature films: they settle the tension between compulsive work and the workers' family life by depicting their ultimate aloneness and unhappiness: Mateusz Birkut's wife leaves him, taking his son, during his "quest for the truth about the sabotage and the disappearance of his friend Witek due to 'alleged contacts with the West'", whereby Birkut became "a dangerous type, impervious to any kind of political and ideological influence from the authorities" (Falkowska 1996: 74). The second wife of Adem, Čengić's main character, a Muslim, is taken away by her father, who claimed Adem "disgraced her by taking off her

${ }^{13}$ In this context the issue, knowledge and representation of the "typical" deserves special place. This, according to Groys, is a key concept of the socialist realist discourse. A good definition that reflects the mature phase in the evolution of the doctrine is provided by Georgy Malenkov, the Soviet Communist Party leader and close collaborator of Joseph Stalin: "As our artists, writers, and performers create their artistic images, they must constantly bear in mind that the typical is not that which is encountered the most often, but that which most persuasively expresses the essence of a given social force. From the Marxist-Leninist standpoint, the typical does not signify some sort of statistical mean... The typical is the vital sphere in which is manifested the party spirit of realistic art. The question of the typical is always a political question. [...] Thus, in the way the typical in the life of society is brought out in the artistic representation, we can see the political attitude of the artist toward reality, social life, historical events" (cf. Groys 2011: 50-51).

${ }^{14}$ Still, in the post-war Yugoslav economy the working hours of shock workers were longer. Here is what Antun Bičić, a shock worker from Raša, "second only to Sirotanović", the recipient of the Medal of Work of the $2^{\text {nd }}$ Order, said in a statement to the Raški rudar (The Raša Miner) newspaper in the mid-1960s: "I loved the mine very much. I still love it. In those years when we were in the competition I spent more time down in the mine than outside. I used to spend as much as twenty hours in the pit, I couldn't get enough" (Milevoj 1991: 35, emphasis added). 
veil", and his third wife, Stefka, a former Slovenian shock worker, was killed by unknown perpetrators because of Adem's quota increase, and because he joined the Communist Party in 1947 - when it was still uncertain "which side would prevail". Petri's Lulù Massa sustains two families, suffers from sexual dysfunction brought on by excessive work in the factory, and tries to keep up a romantic relationship with a work colleague. Elio Petri depicts the Stakhanovite turner as the victim of libidinal transfer, who substitutes his bedroom for the work place, his wife for his turning machine. Before he responds to his wife who complains that he is "never up to it and she has been on the pill for the third month running" with "I don't have a machine between my legs, and I'm only up to it in the morning; when I enter the factory, I could go three times", he explains to his younger co-workers the particularities of his own technique of fulfilling a high production quota:

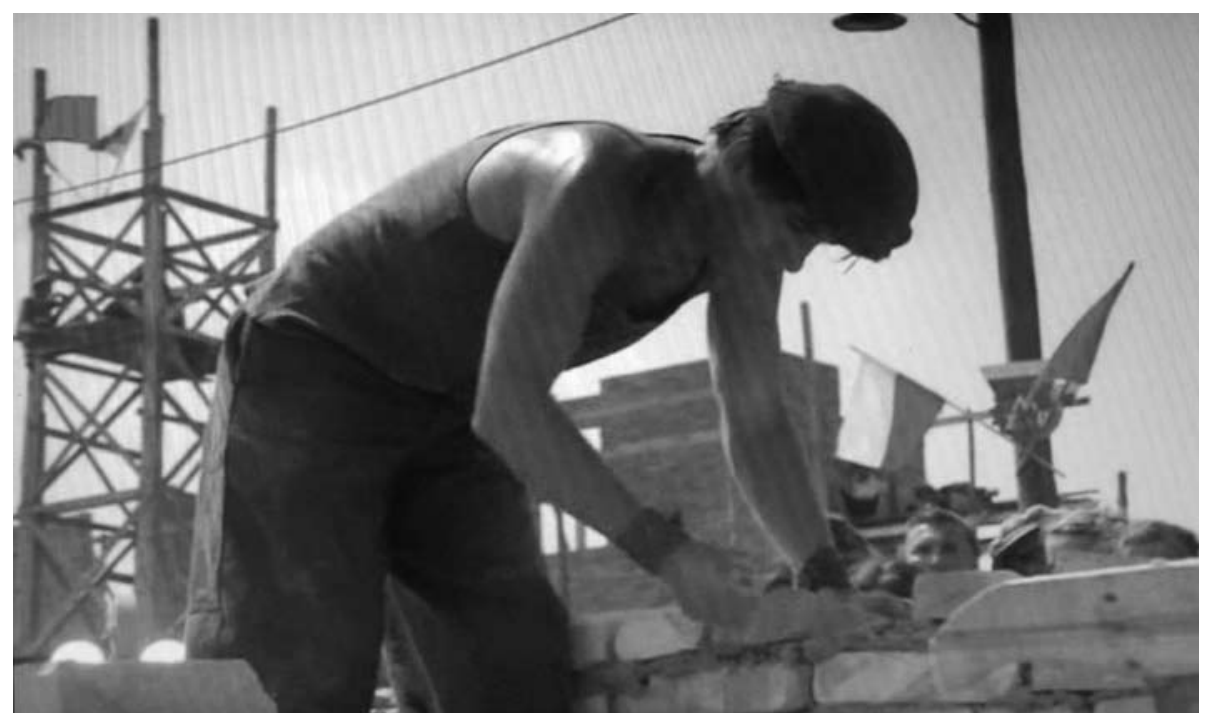

Figure 2. Mateusz Birkut, still from the movie Człowiek z marmuru

I earned 25,000 lira through piecework in a single month! But I'm working, I'm working! I am concentrated, concentrated I tell you, and I have a technique for it. I focus my brain and think of her behind [points to a female co-worker, A.M]. There's nothing else to do here, and since we must work - let's work, am I right?! Enough talk! If I have the strength, I work, I think of the behind, Adalgise's behind [...] watch and learn [...] Thinking only of the piece you're working on, every piece is a hole, every hole is a piece. It is enough not to fall in the hole, and if we don't want to fall in the hole, we have to think of Adalgise's 
behind. And I concentrate, fixate my brain on Adalgise's behind and off I go! Piece - behind, piece - behind, piece - behind, piece - behind...

This story of "production motivation" is reminiscent of sexual abstinence, quarantine that athletes sometimes practice before important matches in order to maximize concentration and performance in the sports field. The comparison is all the more relevant since historically the implementation of Stakhanovism in labor is based on the sports philosophy of competition between workers/brigades/companies. Petri's account of abstinence invites additional interpretations of the analogy: the difference in the "regulation of impulses" between an athlete and Petri's rendition of Lulù lies in the fact that in the case of the former, the ban comes from a transitory external source, and in Lulù's case it has a long-term and internal character - it is represented as aberrant. Moreover, although he calls himself a Stakhanovite, he describes his work to his younger fellow workers as "a job a monkey could do", which is, in our opinion, an explicit and direct link to Gramsci's critique of Fredrick Winslow Taylor's idea of an assembly line worker as a "trained gorilla". This implies "developing in the worker to the highest degree automatic and mechanical attitudes, breaking up the old psycho-physical nexus of qualified professional work, which demands a certain active participation of intelligence, fantasy and initiative on the part of the worker, and reducing productive operations exclusively to the mechanical, physical aspect" (Gramsci 2008: 302). This was to be simultaneous with "the enquiries conducted by the industrialists into the workers' private lives and the inspection services created by some firms to control the 'morality' of their workers [which] are necessities of the new methods of work" (ibid.). In the first part of the film, before becoming aware of his own alienation from the working class caused by losing his finger, Lulù is represented as an example of a worker who not only subjects his life energy and libido to productivity in the workplace, but who also inverts them completely - at work, at the turning machine, he is vital and accomplished in the solipsism of his own work success, and at home he is apathetic, constantly complaining and fighting, obsessed with the factory and profit. Therefore, Lulù's work "emancipation" is not accompanied only by his alliance with the student left, sympathizing with the union, revolt against the foreman and management, but also by sexual emancipation of sorts, a return to the classic working-class machismo. A successful copulation with a work colleague in his car represents a "reversed libidinal transfer" - from the factory and the turning machine to the private space 
and Adalgise's behind, which used to be the primary motivation for the successful performance of established work sequences.

The deconstruction of the monogamous family idyll should be viewed partly in the context of the disintegration of Stakhanovism (and shock labor) as a movement which has "[a]lmost from the beginning contained instructions about how to live as well as how to work [...] Indeed, the nexus between work and rest, factory and home was inextricable. Many of the same qualities Stakhanovites were supposed to exhibit in the one sphere - cleanliness, neatness, preparedness, and a keenness for learning were applicable to the other" (Siegelbaum 1988: 213). In other words, the private and the public were inextricably related. The relation between work and rest, the factory and private space is condensed into a single unit - in order to depict a successful working model there was frequent reference in the mass media to images of a "good private life" in workshops and plants. This stance is maintained by feature film authors; the private and professional spheres remain intertwined, but the qualitative prefix of their relation is changed: compulsive and strenuous work, which had to be enabled and facilitated by the availability of the "abundance of products and all sorts of objects of consumption" (Staljin 1946: 7) in private life, affects shock workers so negatively that it disables them physically. Adem, being "broken with work", complained to his wife in bed that he and his brigade "work two shifts", and that he "headed home yesterday and curled by the side of the road like a rabbit". "And in the morning", he said, "back to the mines. And those above holding meetings and telling us what to do better". She could not but answer: "How am I to do it all alone, Adem? I don't understand anything, why can't you work like everybody else, not work double shifts all the time? You will die, the children miss you, they want a man for a father, not a mole". Čengić contrasts this realist discourse with images, a series of shock labor tableaux vivants which function as counterpoints; they depict an ideal situation, a frozen triumphant image of shock labor, a pose for the audience, the public, which is opposed to the reality of their lives - fatigue, illness and, ultimately, loneliness. ${ }^{15}$ In a

${ }^{15}$ A similar simplistic pattern is followed in the short documentary Alexeij Stachanov: Personaggi (Characters) produced in 1981 by Italian Rai television, dealing with the life of Aleksei Stakhanov - "the living symbol of those who 'work, keep quiet and don't think'. After moving to Moscow, Stakhanov changed - from a work hero he turned into a hero of vice. A bottle of vodka more and more frequently replaced his pick. A superman with a brilliant smile, who proudly advocated honoring the best workers, was now barely able to keep himself standing. Drunk with fame, destroyed by inaction, he experienced the most sinister nightmare of Marxism: alienation. They got rid of him by 
similar manner, Wajda uses a dialogical triad for the same purpose: Jerzy Burski's historical "documentaries" Poczq̨tek miasta (A City is Born) and Oni budujq nasze szczęście (Building our Happiness) ${ }^{16}$ which gave birth to the Birkut cult, the protagonists' and Burski's memories of what went on behind the scenes during the shooting, and the tabooed relationship towards Stakhanovism in the 1970s that Agnieska tries to reconstruct in her documentary about "Poland's most famous construction brick-layer shock worker" from the 1950s. Therefore it is no surprise that the government's project of "culturalization" of workers based on "bringing culture to workers in the form of new cinemas, libraries, parks, reading circles, group excursions, and so forth" (Siegelbaum 1988: 234) became a platform for criticism, irony and distancing in the process of the deconstruction of shock labor. "All sorts of objects of consumption" (Staljin 1935) included the consumption of scientific literature - Wajda portrays Birkut in Burski's documentaries in moments of rest, reading Anton Semenovych Makarenko's Pedagogicheskaya poema (The Pedagogical Poem), published in Russia in $1933,{ }^{17}$ but also doing mathematical problems on the eve of setting a record in laying bricks. In contrast, Čengić ironizes "bringing culture to factory workers" in one of the first scenes of his film, in which the opera Faust (which the miners, who we later learn are illiterate, are watching half-heartedly) is interrupted when the foreman and party leader in the mine comes onto the stage:

Comrades, I've just returned from Belgrade! There is a big shortage of coal!

sending him back to Donbas. His wife and four children didn't follow him. He was buried quietly in 1977 in the land of his mines".

${ }^{16}$ With these pseudo-documentaries, as Rosenstone and Parvulescu write, Wajda actually "'reproduces' the narrative strategies of the Polish Film Chronicle. This means that the viewer who watches, for example, Burski's film Oni budujq nasze szczęście believes to be archival footage. [...] The black-and-white sequences modeled on the documentary footage of the Polish Film Chronicle appear to be a 'realistic' record, an objectivized materialization of the official audiovisual experience of the 1950s" (Rosenstone and Parvulescu 2013: 166).

${ }^{17}$ Makarenko was a dominant educator, whose work was "based on the rehabilitation of children with behavioral problems and juvenile delinquents through work, learning and doing chores. Gorky called his educational work 'an experiment of universal importance'" (Hrvatska opća enciklopedija 2004: 778). Also, Makarenko was a firm believer in the effectiveness of "[...] collective education and the unique function of work, discipline and struggle. His methods were in opposition to praising spontaneity and free creativity of the educated, advocated by Soviet pedagogists of the so-called 'free-school' who deemed Makarenko's methods too difficult and severe (punishing was based exclusively on the collective principle). It was only after a part of the Soviet official pedagogy had abandoned the 'free school' ideal that the success of Makarenko's pedagogy began" (Dizionario di filosofia 1980: 274). 
Comrade Kidrič said that trains and mills would stop in a week. ${ }^{18}$ It's up to us to mine as much coal as we can. We talked, man to man - production must increase! We have to compete among ourselves, see who can give more. Miner against miner, coalmine against coalmine! This is the beginning of the second underground revolution! In Russia Stakhanov, their best miner, mined 102 tones in a single shift, and he was competing, too. I was listening and thinking - maybe I should enter our mine in the competition, to set an example. Our engineer kicked me under the table - "but we have no men". "What do you mean, we have no men? We have Adem, Mijatović, Škorić, Alija, Babajić - are they men or aren't they!?" So, I raised two fingers and entered our mine in the competition. If it was a mistake, don't hold it against me.

The proposal is accepted with applause and Adem chooses the men to go with him, he creates his work brigade by himself and invites those of his colleagues he wants to work with to the stage. This scene can be interpreted as the beginning of a "show" in which the workers (proletariat) assume the leading role of the bourgeoisie (actors), but also as the finale of the interrupted Faust, whose role and destiny is taken over by the shock workers, accepting the Party's proposal. Starting off as the chosen ones, the lucky ones (in the etymological sense, from the Latin fäustu(m), or favēre, originally meaning "to prefer", but also "happy", "cheerful"), in time they become infàusti. ${ }^{19}$ In the last sequence of the movie, Čengić shows the shock worker Adem twenty-five years later as a janitor in a modern factory, where none of the workers notices, honors or remembers him (Goulding 2004: 114). Mortality for the glorified heroes of work, the director suggests, comes with anonymity, which is in line with what he said about his film in an interview given to TV Slovenia - "I found Alija Sirotanović in his village near Breza; I found him completely forgotten and, I have to say, unhappy" (Čengić, interview, author's personal archive).

The idea of raising the level of culture of the workers through shock labor, Stakhanovism, had to be one of the markers of the transition between the socialist and communist society, ${ }^{20}$ and it implied the "annihilation of

${ }^{18}$ Boris Kidrič was the Minister of Industry in the Federative People's Republic of Yugoslavia from 1946 until his death in 1953.

${ }^{19}$ Infausto is term used in Romance languages to denote pain, grief, unhappiness, but also mortality.

${ }^{20}$ Socialism in this case refers to the present political order with all its difficulties, inequalities and flaws, a sort of a political phase that precedes communism as a political and social concept of a more egalitarian and righteous society that has to be achieved in the future including, among other characteristics, the disappearance of differences between manual and intellectual labor, including 
the polarity between intellectual and physical work which can be achieved only through increasing the cultural and technical level of the working class" (Staljin 1935: 8). The philosophical theory of annulling the opposition between intellectual and manual labor was developed three years before Stalin's speech, in 1932, by Antonio Gramsci in his Quaderni del carcere, albeit based on somewhat different and more elaborate premises:

When one distinguishes between intellectuals and non-intellectuals, one is referring in reality only to the immediate social function of the professional category of the intellectuals, that is, one has in mind the direction in which their specific professional activity is weighted, whether towards intellectual elaboration or towards muscular-nervous effort. This means that, although one can speak of intellectuals, one cannot speak of non-intellectuals. [...] There is no human activity from which every form of intellectual participation can be excluded: homo faber cannot be separated from homo sapiens. Each man, finally, outside his professional activity, carries on some form of intellectual activity, that is, he is a "philosopher", an artist, a man of taste, he participates in a particular conception of the world [...] and therefore contributes to sustain a conception of the world or to modify it, that is, to bring into being new modes of thought. [...] In the modern world, technical education, closely bound to industrial labour even at the most primitive and unqualified level, must form the basis of the new type of intellectual. [...] The mode of being of the new intellectual can no longer consist in eloquence, which is an exterior and momentary mover of feelings and passions, but in active participation in practical life, as constructor, organizer, "permanent persuader" [persuasore permanente] and not just a simple orator (but superior at the same time to the abstract mathematical spirit); from technique-as-work one proceeds to technique-as-science and to the humanistic conception of history, without which one remains "specialized" and does not become "directive" (specialized and political). (Gramsci 2008: 9-10) ${ }^{21}$

the remuneration for them.

${ }^{21}$ This was, according to Christine Buci-Glucksmann, part of his attempt to distinguish "the 'philosophy of praxis' from other philosophies" where Gramsci proposes "the status of contradiction" as criterion. "Whereas other philosophies are 'inorganic, because contradictory creations', the philosophy of praxis 'does not tend to resolve contradiction in history and society peacefully, but is the very theory of these contradictions'. [...] 'It is the expression of these subaltern classes, who want to learn the art of government and have an interest in knowing every truth, even most disagreeable'. [...] For Gramsci, however, as for Henri Barbusse, if everyone is a philosopher, the basic reason is that a philosophy already exists at the practical level in language, in good sense, and in what Gramsci calls folklore, understood in the broad sense of a 'system of beliefs, superstition, opinion, ways of seeing and acting. The notion of a 'spontaneous philosophy', which can already be found in Engels, and was to be taken up by Althusser, is simply a generic term for grouping 
How can the shock labor movement be embedded in this concept of the "new type of intellectual" and, more importantly for our present purpose, how do feature film directors represent this ultimately political attempt at involving a part of the "working people" in the milieu that enabled this kind of emancipation through "increasing the cultural and technical level"? In Gramscian terms - were shock workers (represented as persuasori permanenti in the films) representatives of this new type of intellectuals - "directives", taking into account that after the war care was taken to cultivate their image as technical intelligentsia (they often gave speeches to large audiences side-by-side with politicians and engineers) as well as their hands-on involvement in visiting various working collectives to instruct the workers on their advanced working techniques?

\section{POLITICAL EXCLUSION}

In his book The Total Art of Stalinism Boris Groys analyzed the significance of the inclusion of many writers, artists, and filmmakers in privileged party circles, where they were encouraged to take direct part in Stalin's apparatus of power. According to Groys, this was not the case of a classic "bribe" - people from the cultural milieu could be intimidated, just like anyone else. Rather, the crucial issue was that they had the opportunity to catch a glimpse of the "typical", which had to be reflected in their work. So, being part of the leadership meant taking part in decision-making. Therefore, the Soviet artist-as-a-party-bureaucrat, Groys concludes, was a greater artist, a greater creator of new reality than the one sitting in his

together the set of sentiments, ways of living and thinking that are specific to subaltern strata, and it paves the way for a new and specifically Gramscian object: a history of these subaltern strata" (BuciGlucksmann 1980: 224-225). If we compare Gramscian “subordinate classes" with Sartre's writings on the native of Ambrym, referred to by Lévi-Strauss in his famous discussion, we can see that from the ethnological perspective the author of the Critique of Dialectical Reason had a different view on "spontaneous philosophy". In the words of the French ethnologist "[i]t seems even less tolerable to him than to Lévy-Bruhl that the savage should possess 'complex understanding' and should be capable of analysis and demonstration. Of the Ambrym native, made famous by Deacon's work, who was able to show the field-worker the functioning of his marriage rules and kinship system by a diagram in the sand (an aptitude in no way exceptional as plenty of similar cases are recorded in ethnographic literature) Sartre says: 'It goes without saying that this construction is not a thought: it is a piece of manual work governed by unexpressed synthetical knowledge'. Granted: but then the same must be said of a professor at the École Polytechnique demonstrating a proof on the blackboard, for every ethnographer capable of dialectical comprehension is intimately persuaded that the situation is exactly the same in both cases" (Lévi-Strauss 1966: 251). 
studio (Groys 2011: 52). This interweaving - or, in Groysian terms, insight into the milieu of the political leadership with the purpose of a better understanding of one's own obligations within the political-ideological framework - also applied to Stakhanovites, shock workers. For example, in the film The Stakhanov Movement Stalin's speech in the Kremlin, attended by Grigory Ordzhonikidze, ${ }^{22}$ Vyacheslav Molotov, Lazar Kaganovich, Kliment Voroshilov, but also by work heroes Aleksandr Busygin, Pasha Angelina and Petr Krivonos, is preceded by Stakhanov's speech, as the editing suggests. Groys's example of artists as members of the "privileged profession" is embedded in the construct of shock labor, since one should bear in mind that one of the results of mass industrialization was the "automatic" deterioration of the noble craft and skill which brought about the inseparability of art and serial production in a single object. In its own way, Stakhanovism introduced a rehabilitating and reanimating force into this "lost" world by emphasizing the nobility, genius and creativity of shock workers, whose manual and intellectual work was represented as unique in its volume and individualized mode of production (cf. Matošević 2011: 233)..$^{23}$

However, although it was typical of the post-war period to present "work categories, professions and classes as a bricolage", a blend of elements, which was done to achieve an amelioration in production and symbolic status, the three feature films, especially Człowiek $z$ marmuru and Slike iz života udarnika, refer to this element of the shock-labor image only sporadically. Andrzej Wajda shows Mateusz Birkut at the peak of his glory and success in the pseudo-documentary Oni buduja nasze szczęście as one of the main protagonists of a New Year's ball, taking place in a festively decorated main hall of the Warsaw Polytechnic, reserved only for the most deserving - "[i]ndividuals from the Party and the government, leading workers, farmers and teachers. One of them is Mateusz Birkut, a

${ }^{22}$ However, since Ordzhonikidze, the first man of Soviet heavy industry, died in 1937, the film could not have been made in 1938, as suggested on the web-page where the film is available. It is more probable that the distribution started in 1938.

${ }^{23}$ From this demiurge-like perspective there are two possible views on shock labor in Soviet and Yugoslav documentaries. On the one hand, quantity becomes equivalent with quality; quantities, volumes and exceeded quotas are the most frequent topics, while the technical modus required to accomplish them is rarely mentioned. On the other hand, we can interpret the symbolic part of the movement's industrial production through the prism of an attempt at an inversion of values - the former "dirty industry" is described using new words, in "artistic" terms - as a "poem" or "symphony", representing an attempt to habilitate or "transfer" the socially marginal profession to the central symbolic sphere, to the managerial and the political. 
leading worker from Nowa Huta, chosen by his comrades as the delegate for the Construction Workers' Convention and later leading the Workers' Convention. Men like Birkut became the inspiration for artists. A marble statue [of Birkut, A. M.] takes form, a symbol of our construction worker". Certainly, Birkut's success and inclusion in the ruling structures are used to better illustrate the downfall of shock workers, their fall into oblivion, and, consequently, pietas "as a term evoking mortality, finality and transience" (Vattimo 2008: 117), as well as compassion and pity, the dominant elements in the description of the first generation of work heroes in the post-shock labor period, when these films were made. It is important to point out that Wajda presents Birkut's rise to becoming the Hero of Work and Poland's first construction worker eclectically; he is critical of its constructedness, although apologetic of its most significant result - the shock worker Mateusz Birkut:

This sequence transports the spectator into another world, compelling him to compare the historical discourse presented by Wajda with whatever he knows, thinks, or realizes concerning the 1950s. The reaction of older spectators, upon the film's release, was especially violent in regard to this scene since they recognized whole areas of associations that they dialogically related to their own experience. In this sequence, Burski decides to produce a tour de force, a staged screening of the workers' race for the best construction results. The first secretary, Jodla, the security members, and the film director all take part in the conspiracy. However, the final word concerning the arrangement of the mise en scène, the action, and the choice of actors belongs to the director. Party corruption goes hand-in-hand with a cynical manipulation by the media. The event Burski orchestrated was the construction of a wall of 35,000 bricks within one day. Such an event had to be carefully prepared, and a worker had to be chosen who would not jeopardize the propagandist value of the whole event. He had to be extremely naïve, young, and strong. Birkut served this ideal in the best way imaginable. (Falkowska 1996: 71)

However, leaving aside the ambiguity of the sentence in which Falkowska refers to the "violent reaction" of older spectators (since it is unclear whether they saw the truth or uncovered a lie; whether they interpreted the scene as undermining the socialist mythology they believed in or as presenting a lie they were forced to support), it is paradoxical that Wajda's film actually upholds the myth of Stakhanovism. Birkut not only accomplishes his goal, he does it despite the corruption in the system that made him 
in the first place; he exceeds the production quota without "cheating", through strenuous work, and after realizing what he had become part of, his conscience remains clear and he fights Party's decision as only a shock worker can. His actions earn him the accusation of being the "wrecker of the system":

The figure of the wrecker that is so important to Stalinist mythology is no more "realistically motivated" than the superhuman power of creation in the "positive hero". The show trials of the 1930s demonstrated that seemingly quite normal persons were capable of strewing ground glass in the food of the workers, giving them smallpox and skin disease, poisoning wells and public places, infecting livestock with anthrax, and so on. Moreover, they did all this on a superhuman, unimaginable scale, accomplishing the most titanically destructive feats in many places at the same time but without any technical or organizational assistance (since that would eliminate their individual guilt), and by will-power alone (since they were the whole time working for the party and under its supervision). (Groys 2011: 61)

Wajda's Birkut, it seems, supports both sides of this mythology - he starts off as a hero of work and soon after a show trial becomes a prisoner. However, what is more significant is the lingering leitmotif of the naïve shock worker. Although the shock-worker movement is part and parcel of the state socialist system and although its political and economic impact was by no means insignificant, Čengić and Wajda used its protagonists to deconstruct the credibility of the system and its project of equality, i.e. to expose its hollowness and falsehood, reusing the shock workers, or the idea of who they are, as living relics of the system's injustice toward the individual. What the two movies, Człowiek z marmuru and Slike iz života udarnika, have in common, however, is the fact that the main actors - shock workers - remain (regardless of their engagement in the workers movement) completely passive when it comes to grasping the constructedness of their success and the scheming and plotting that enabled it. Adem and Birkut, allegories of the time and the first generation of Stakhanovites outside the Soviet Union, are shown as victims of their own success. Everything surrounding them is corrupt - the movement is artificial, constructed by the media, a happy family life and purchasing power turned into their opposite - poverty and despair, everything is fake $e^{24}$ except for themselves, who are depicted

${ }^{24}$ We later find out that Birkut had in fact never been married to Hanka Tomczyk; their wedding ceremony was staged by the Party since Hanka was too young for marriage. 
as unconscious of the ideological structure whose base was built around their lives. Being "a young man from a village", Wajda's hero "knew nothing about the manipulation by the media; in his naiveté he just wanted to be a good worker and comrade. Birkut was presented as a very naïve person, a peasant who believed in the ideals and purposes of the Marxist ideology" (Falkowska 1996: 71). We find a similar sequence of narrative images in Miljenko Jergović's account of the figure of Alija Sirotanović:

He was our worker, although we recall him only as an old, retired man, because we were too young to remember a time when work had the meaning of progress, when people believed in communism in a way one believes in the immortality of the soul in moments of happiness and exaltation. [...] They were dinosaurs undergoing extinction and a reminder of a time when people did not go to school or college, but to mines and factories. [...] And Alija, poor man, he mostly kept quiet, answering journalists' questions shyly like a little girl, and he was old as only a miner can be, with wrinkles deep as ours will never be. [...] They talked reluctantly, they talked sparingly and they were ashamed. What were the workers ashamed of, what was Alija Sirotanović ashamed of, we will never know. [...] If there is heaven, Alija Sirotanović is giving away banknotes with his face on them, and their eyes swell up with tears. (Jergović 1999)

However, in order to leave heroes of labor untainted, honest in their intentions and deeds, the authors necessarily view them through a prism of simplicity, naivety and sincerity, ${ }^{25}$ bordering on "mental inferiority", never explicit, but visible from the context. The integrity of the shock workers, the examples suggest, can survive only if they are infantilized.

Such a conclusion also raises a set of questions concerning Wajda's position: is Wajda in fact Burski, does he build his career on the idea of allegorized shock labor, constructing it for political purposes in a manner similar to Burski's? ${ }^{26}$ If documentaries about shock workers (the genre

${ }^{25}$ An informant I spoke with in 2012 during my research on Stakhanovism, who had met Antun Tone Bičić, the shock worker from Istrian collieries and the protagonist of Rudolf Sremec's Događaj $u$ Raši, told me a similar story: "He was a really good man, I respected him a great deal, but later on he was not respected any more, people forgot all about him, I don't know why. His wife was a hag, an

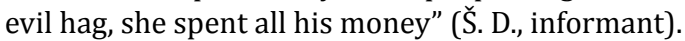

${ }^{26}$ Andrzej Wajda's Człowiek $z$ marmuru won the Critics' Award at the Polish Film Festival in 1977 and the FIPRESCI Prize in Cannes in 1978, while Człowiek $z$ żelaza was nominated for an Oscar in the Best Foreign Film category in 1982 and won the Palme d'Or in Cannes in 1981. The same movie won the French César and London Critics Circle Film Festival Award in 1982. Just like Burski, whom Wajda depicts as a director whose career is based on the construction of the character of an 
and topic Wajda refers to through Burski's early work) were to serve as part of "rhetoric of social elevation" within the framework of an idealized representation of a process in which "all sides claim to be winners" (Wells Greene in Berger et al. 2005: 69), then the "feature" part of Człowiek $z$ marmuru directly and in a simplifying manner depicts the losing flipside of the "victory" as a means of political struggle and emancipation. ${ }^{27}$ This is the segment that Čengić's and Wajda's films have in common, they both serve as strong signifiers of the idea of shock workers' defeatism and misery, which form the constitutive elements of the re-signation process that the movement underwent starting with the 1970s, when film directors took it under proper artistic patronage. However, these two films underplay the concept of work and the increase of quotas, which is crucial for the

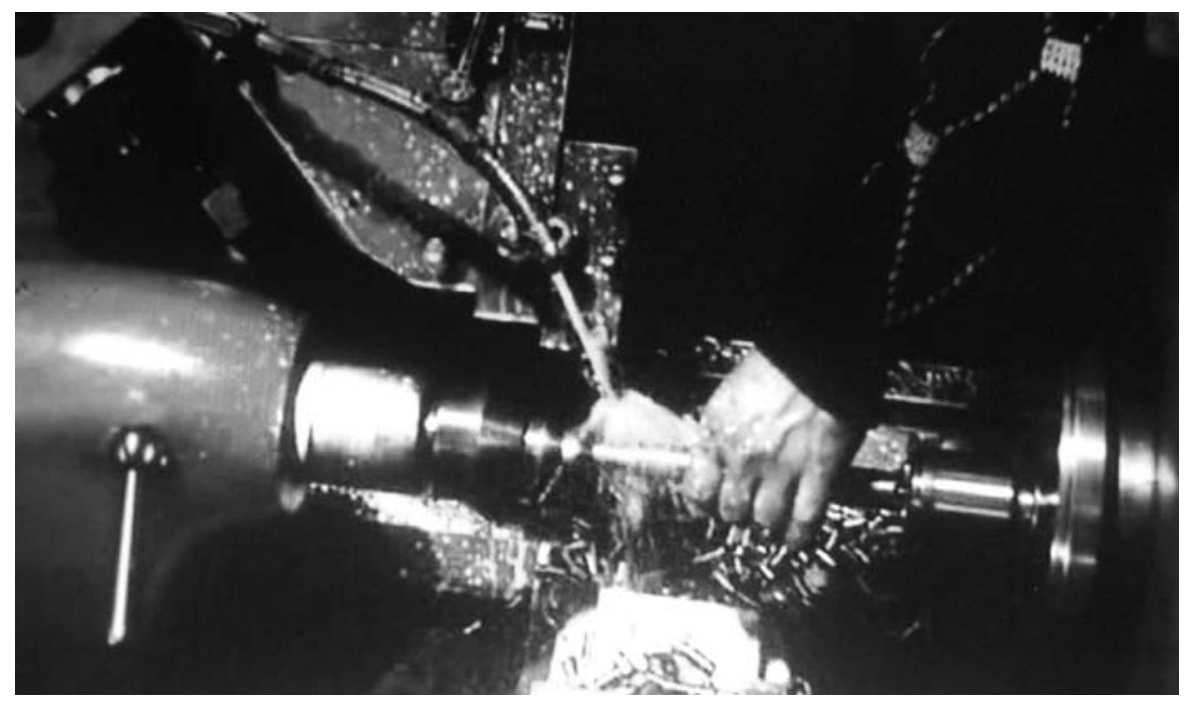

Figure 3. Lulù Massa's finger, still from the movie La classe operaia va in paradiso

interpretation of Stakhanovism. Chronologically the first in the analyzed triad, La classe operaia va in paradiso, underlined this as the central segment in the micro-politics of work relations.

exemplary shock worker, Wajda's own career is based on the "deconstruction" of that idea.

${ }^{27}$ Certainly, Mateusz Birkut's destiny is to be interpreted in the context of the whole this film forms with Człowiek z żelaza, the movie featuring his son Maciek Tomczyk as one of the leaders of the Solidarność movement in the shipyards of Gdańsk and Birkut's death by an army bullet. If we interpret the work heroes' endings through Wajda's films, it appears that they uphold the thesis that shock workers were victims of the system they themselves enthusiastically helped build. 


\section{WORK}

The Italian stacanovista, the turner in Elio Petri's film, is not the enthusiastic hero making a sacrifice for a more just future; his "petty motivation" at the expense of the well-being of the work community does not sit well with the other workers in the factory, and it all culminates in a punishment, his physical mutilation. In other words - while Wajda and Čengić recognize the system or individuals, especially bureaucrats, film directors and officials surrounding the shock workers as the sources of perversity - Petri locates the quintessence of the "production contradiction" and the ethical ambivalence of complying with piecework at the heart of Stakhanovism. Lulù Massa is not represented as a naïve fellow and a good comrade; he is interested only in money and its equivalent in commodities, at least until he loses his index finger on a turning machine. ${ }^{28}$ However, the turning point in the film is when he turns from a "top worker" to a "fierce opponent" of timed piecework during a conversation with the foreman:

- Lulù, what are you doing? Your performance is so bad! You've got to get into it, you'll lose your fixed piecework. Maybe you got rusty during the holidays?

- Rusty? Yeah right! Look, leech, look. It's not that I can't, I don't want to! I have other things on my mind!

- But your time is really bad, poor, a child would do better.

- A child? Because they don't treat us like kindergarten children here? Like we are in a juvie, more like it!

- Look, if you keep this up, Lulù, you'll remain below quota, you'll not only lose your earnings, but I'll have to punish you!

- Ah, punishment, punishment! Why don't you punish me, c'mon, punish me. But after that, you'll have to give back everything you stole from me when I was a Stakhanovite, you'll have to shit it all back! Including the finger!

The infantilization Lulù mentions is different than Birkut's, even opposite to it: the latter stems from the "(rural) character" of the exemplary worker while the former stems from being a turner, a job "a monkey could do", according to one of the protagonists. Therefore, there is a clear

\footnotetext{
${ }^{28}$ Moreover, the final scene of the movie is dominated by a large drawing of a fist with the index finger pointing to the floor, representing the imperative symbol of the last station of the mechanical production process. The drawing oversees Ennio Morricone, the author of the music in the film, in his role of the unqualified worker unloading packages.
} 
distinction between manual and intellectual work, technical execution and its creative precondition. Notwithstanding the differences between the two films, the first part of La classe operaia va in paradiso, preceding Lulù's "class disillusionment" and psychological breakdown caused by the purposelessness of this disillusionment, is best summed up by a demotivating declaration from the closing sequences of Slike iz života udarnika and a conversation with the shock worker Adem - "This is a matter of numbers, not of heart". ${ }^{29}$

On the other hand, Petri's film can, grosso modo, be divided into two parts, and they repeat the issues of the relationship between man and machine, workers and maximization of production, historically expressed in Stalin's famous replacement of - "technology decides everything' with 'the cadres decide everything"' (Groys 2011: 58). Viewed from this perspective, the American-English version of the title - Lulù the Tool is indicative. The film begins with the scene of workers entering the workshop, as the following monologue greets them from the PA system:

Good morning, workers. The management wishes you a good morning. It is in your interest to handle with love the machine you have been entrusted with. Maintain it well. The company's security measures guarantee your security. Your health depends on your relationship with the machine. Respect its needs and don't forget that the machine combined with care result in production. Have a good working day!

Petri relates this need to put the emphasis of the production process on the primacy of machines, instead of the man, the worker, to a subsequent inversion of this order of things. This need represents a condensed and a locally embedded version of a much wider and more long-lasting philosophical debate. In his Quaderni del carcere Antonio Gramsci criticized

${ }^{29}$ This part of the film, the last eight minutes or the last 150 meters of the tape, was cut out after being shown at the Festival of Yugoslav Feature Film in Pula 1972. Also, as suggested by an insert in a restored version of the film, the following dialog was cut out:

- Worker: Workers, what is happening to us?

- Adem: I don't know.

- Worker: Are you going to Germany, Adem?

- Adem: And what am I gonna do there...

In addition the fact that this dialogue was probably one of the reasons why the movie was taken out of the competition at the Festival of Yugoslav Feature Film in Pula, it also corroborates the thesis of shock workers' disappointment with their treatment by the authorities after their successes were accomplished. Heroes who build a country with their own hands no longer have any place to live or work in that country. They are expected to become expatriates and Gastarbeiters. 
Nikolai Bukharin's twofold division of Marxism - into philosophical Marxism and scientific sociology - that resulted in the prevalence of mechanical materialism and natural sciences in Bukharin's Marxism. György Lukács joined this criticism:

Bukharin "frequently obscures the specific feature of Marxism: that all economic or 'sociological' phenomena derive from the social relations of men to one another". This theoretical error, in which Bukharin departs from the authentic tradition of Marxism, and his scientific and naturalistic orientation, led to mechanistic and evolutionist position marked by fetishizing of the technical instrument, as the motive force of revolution. (Buci-Glucksmann 1980: 218$)^{30}$

\section{What Gramsci takes under attack is a}

false conception of the material forces of production, which are reduced to the technical instrument alone, whereas in reality the working class is the principal productive force [...]. The consequence is that the machine is not just an isolated or isolatable technical object, but an object of production and of property, crystallizing "a social relation, as a moment of the material forces of production". (cf. Buci-Glucksmann 1980: 219)

Petri's reference to the part of the "man-machine" dialectics is transcended by the fact that his main character always acts as a Stakhanovite - during production at his turning-machine as an exemplary worker he is as vital as in his later role of a conservative anti-capitalist: "Petri suggests that these two apparently opposite positions are much closer than they might seem, for the degree of jouissance spent by the subject who fanatically obeys the law can easily be converted into a subversive libidinal force" (Vighi 2006: 100). ${ }^{31}$ This is what Lulù Massa and Mateusz Birkut have in common. The latter changes from an exemplary worker, a hero of work (on whose work technique, a central part of the Stakhanovite mythology, the movie reports very little) into a "dangerous guy", uncompromising in his quest

${ }^{30}$ According to Christine Buci-Glucksmann, Lukács claims that it is "obvious that this final identification of technique with the forces of production is neither valid nor Marxist. Technique is a part, a moment, naturally of great importance, of the social productive forces, but it is neither simply identical with them, nor [...] the final or absolute moment of the changes in these forces" (cf. Buci-Glucksmann 1980: 219).

${ }^{31}$ This interpretative political relativism is visible in Petri's film and, according to Fabio Vighi, it anticipates the author's conversion to Buddhism (Vighi 2006: 194). 
for justice. Moreover, this transformation leads to his complete withdrawal from the public life, his abandonment and half-heartedness. However, $L a$ classe operaia va in paradiso is the only film in the triad under scrutiny that puts emphasis on the negative micro-dynamic repercussions that the continuous increase of production quotas - a sine qua non of Stakhanovism - has for the whole working community. These repercussions vary from the physical inability of older workers to keep up with the increase of production rhythms due to the swelling of their prostate to the open expressions of animosity and insults directed at exemplary workers. On the other hand, the film painstakingly outlines the analytical indivisibility of Stakhanovism and the economic philosophy at its roots - Taylorism. Still, in the 1970s, when Petri undertook his celluloid analysis of the status quo in work facilities, Čengić and Wajda made historical movies about the post-war period, which enabled them to portray the features of the first generation of Stakhanovites which are missing from the Italian movie - work enthusiasm and production results that are not mediated by financial incentives but rather have the character of a gift, a potlatch, where work success always has to be larger and thus more pompous than the previous.

\section{CONCLUSION}

In the late 1990s, the journalist and writer Mile Stojić, contemplating on the complex issue of a "generation's right to forget the actions of its own fathers" in his column entitled Obnova (Restoration), wrote that our fathers brought us songs from the so-called youth work actions, from the builders of the Šamac - Sarajevo and Brčko - Banovići railways, from the architects of Vranduk. We forgot Alija Sirotanović, a hero whose body supported the mammoth construction of a collective utopia like a marble caryatid. We didn't have our Andrzej Wajda to immortalize the engine of our progress before we destroyed it ourselves (Stojić 1998). Still, we may say that Yugoslavia had "its Wajda": Bata Čengić's film recapitulated the project of shock labor and, in Gianni Vattimo's terms, re-signed it with characteristics which include, among others, the phonetic aspect of the term re-signation. The resignation of exemplary workers in movies, the topos of narrative ellipsis that represents them, is no truer than their unconditional infectious enthusiasm depicted in the post-war "documentary" films. While the post- 
war documentaries are lacking in the accounts of the hazards of and the lack of recognition accompanying hard physical labor, the emphasis on the latter in feature films does not necessarily lead to the heart of the matter of shock labor. Still, it allows for depicting the idea and the period as "excessive and grotesque in terms of politics and propaganda, but also naively enthusiastic" (Goulding 2004: 110-115). If we agree with Boris Groys's claim that "East-European art is viewed as East-European; as a source of information of the conditions in the societies it originated from" (Groys 2003: 179) and apply it to the issue of the representation of shock workers, it turns out that the movies made in the 1970s become their dominant signifiers, an "authoritative source of information" and of "historical data" par excellence. As opposed to that, the Italian film underlines several important aspects of this labor phenomenon, often considered typical only of state-socialist countries. First, it corroborates the fact that Stakhanovism had a much wider geopolitical application and, consequently, an artistic response to its problematic aspects; but more importantly - it contributes to our understanding of possible personal repercussions it had in factories. The latter thus functions better than Čengić's or Wajda's films as a sort of a micro-social veristic counterpoint to the grandiose mythopoetic discourses developed within the nostalgic post-socialist framework; e.g. Jergović's or Stojić's writings cited above. But the political repercussions for all the films (including La classe operaia va in paradiso) which dared touch the sore spot of (early) socialism or work organization - e.g. the removal of Čengić's film from the Festival of Yugoslav Feature Film in Pula in 1972, its ban and cutting the tape of the final part of the movie, Wajda's leaving Poland, the attempt to prevent his Oscar nomination and the indifferent and almost critical reception of Petri's film on the part of the Italian left - all represent a continuation of the shock work dialectics between artistic advocacy of the movement or its exemplary individuals and the system that generated them. 


\section{REFERENCES AND SOURCES}

Berneri, Marie Louise. 1942. "Stakhanovism and the British Workers". At http://libcom.org/history/stakhanovism-british-workers (accesed 15 February 2013).

Buci-Glucksmann, Christine. 1980. Gramsci and the State. London: Lawrence and Wishart.

DiCaprio, Lisa. 1982. "Man of Marble, Man of Iron. Polish film and politics”. Jump Cut 27: 7-12. Dizionario di filosofia. 1980. Sordi Italo, ed. Milano: Rizzoli editore.

Falkowska, Janina. 1996. The Political Films of Andrzej Wajda. Dialogism in Man of Marble, Man of Iron, and Danton. Providence and Oxford: Berghahn Books.

Goulding, Daniel J. 2004. Jugoslavensko filmsko iskustvo, 1945. - 2001. - oslobođeni film. [Luka Bekavac, trans.]. Zagreb: V.B.Z.

Gramsci, Antonio. 2008. Selections from the Prison Notebooks. Quitin Hoare and Geoffrey Nowell-Smith, eds. and trans. New York: International Publishers.

Groys, Boris. 2003. “Povratak iz budućnosti”. Tvrđa 1-2: 179-182.

Groys, Boris. 2011. The Total Art of Stalinism. Avant-Garde, Aesthetic Dictatorship, and Beyond. London and New York: Verso.

Hrvatska opća enciklopedija, Svezak 6. 2004. August Kovačec, ed. Zagreb: Leksikografski zavod Miroslav Krleža.

Jergović, Miljenko. 1999. “Alija”. Dani 102. At

http://www.bhdani.com/arhiva/102/citanka02.htm (accesed 12 December 2012).

Lévi-Strauss, Claude. 1966. The Savage Mind. London: Weidenfeld and Nicolson.

Majdin, Zoran. 2011. "Lik i delo. Alija Sirotanović”. Vreme 1061. At http://www.vreme.com/cms/view.php?id=989288 (accessed 14 November 2012).

Matošević, Andrea. 2011. “'Život je radostan drugovi udarnici!' 0 'žrtvovanoj' generaciji demijurga socijalističkog etosa”. U Horror-Porno-Ennui. Kulturne prakse postsocijalizma. Ines Prica and Tea Škokić, eds. Zagreb: Institut za etnologiju i folkloristiku, 219-241.

Milevoj, Marijan. 1991. Do socijalizma i natrag. Labinska novinska kronika 1945. - 1990. Labin: Labinska komuna.

Morandini, Laura, Luisa Morandini and Morando Morandini. 2002. Il Morandini. Dizionario dei film. Bologna: Zanichelli editore.

Rosenstone, Robert A. and Constantin Parvulescu, eds. 2013. A Companion to the Historical Film. Chichester: Wiley-Blackwell.

Siegelbaum, Lewis H. 1988. Stakhanovism and the Politics of Productivity in the USSR, 1935-1941. Cambridge: Cambridge University Press.

Staljin, Josif. 1946. Govor na prvom svesaveznom savetovanju stahanovaca 17. novembra 1935. godine. Beograd and Zagreb: Kultura.

Stojić, Mile. 1998. “Obnova”. Dani 83. At http://www.bhdani.com/arhiva/83/fokus83.htm (accessed 2 December 2012). 
Vattimo, Gianni. 2008. Čitanka. Zagreb: Hrvatsko društvo pisaca and Izdanja Antibarbarus.

Vighi, Fabio. 2006. Traumatic Encounters in Italian Film. Locating the Cinematic Unconscious. Bristola and Portland: Intellect Books.

Wells Greene, Janet. 2005. "Cameras in the Coalfields: Photographs as Evidence for Comparative Coalfield History". In Towards a Comparative History of Coalfield Societies, Stefan Berger, Andy Croll, and Norman LaPorte, eds. Aldershot, Hampshire and Burlington: Ashgate, 65-85.

Zingarelli, Nicola. 2008. Vocabolario della Lingua Italiana. Bologna: Zanichelli editore.

\section{FILMOGRAPHY}

Alexeij Stachanov: Personaggi. At

http://www.raistoria.rai.it/articoli/alexeij-stachanov-personaggi/6907/default.aspx (accesed 2 February 2013).

La classe operaia va in paradiso. Elio Petri. Euro International Films, 1972.

Slike iz života udarnika. Bata Čengić. Studio film, 1972.

Człowiek z marmuru. Andrzej Wajda. Zespół Filmowy X, 1976.

Człowiek z żelaza. Andrzej Wajda. Zespół Filmowy X, 1981.

"Aleksei Stakhanov". 1936. At

http://www.soviethistory.org/index.php?page=subject\&show=video\&SubjectID=19

36stakhanov\&Year=1936\&navi=byYear (accesed 2 February 2013).

“Happy Housewarming, Comrade Busygin!". 1936. At

http://www.soviethistory.org/index.php?page=subject\&show=video\&SubjectID=19

36stakhanov\&Year=1936\&navi=byYear (accesed 2 February 2013).

"The Stakhanov Movement". 1938. At

http://www.soviethistory.org/index.php?page=subject\&show=video\&SubjectID=19

36stakhanov\&Year=1936\&navi=byYear (accesed 2 February 2013).

Sto dana u Brezi. Documentary. Zoran Markuš. Zvezda, 1949.

Filmski Pregled broj 5. Documentary. Branko Bauer. Jadran-film, 1950.

Događaj u Raši. Documentary. Rudolf Sremec. Jadran-film, 1950.

\section{OTHER (AUTHOR'S PERSONAL ARCHIVE):}

Š. D., interview. 15 September 2012 in Pula.

Čengić, Bata. Interview, TV Slovenija.

Šuvar, Stipe. Press conference. Festival of Yugoslav Feature Film in Pula 1972. 